\title{
Application and comparison of proteolytic enzyme preparations in technology of protein hydrolyzates
}

\author{
Aleksandr LUKIN ${ }^{1 *}$
}

\begin{abstract}
Protepsin belongs to the class of acid proteinases, containing carboxyl groups in the active center. The preparation cleaves peptide bonds formed by aromatic amino acids (tyrosine, phenylalanine), and does not hydrolize esters and amides. Along with the proteolytic complex, Protepsin contains collagenase, lipase, and other digestive enzymes. The preparation is obtained according to the original technology through maceration of animal endocrine raw materials, followed by purification, concentration, isolation and freeze dehydration of the enzyme complex. The results of the laboratory studies of the proteolytic activity of enzyme preparations show that Protepsin, the preparation of animal origin with a proteolytic activity of $100 \mathrm{units} / \mathrm{g}$, has the greatest collagenase activity in the biomodification of native collagen-containing raw materials.
\end{abstract}

Keywords: enzyme preparations; Protepsin; cattle by-products; proteolytic activity; protein hydrolysate.

Practical Application: Processing of secondary collagen-containing products of the meat industry.

\section{Introduction}

Nowadays food industry is among a large number of modern biotechnological industries the successful development of which is in no small way determined by the implementation of technology involving enzyme preparations. The creation and introduction of innovative technologies has greatly expanded the scope of application of enzyme preparations. Today, enzymes help improve product quality, increase its safety, boost technical efficiency, reduce production costs and human impact on the environment (Bobuş, 2010; Spohner et al., 2015).

Proteolytic enzyme preparations are of particular importance, since they are associated with the transformation of protein the main component of human constructive metabolism. They constitute the largest segment of the world market of enzymes, and it is with their use that the search for new sources and forms of protein foods is carried out. Proteases catalyze the hydrolysis of peptide bonds and, along with their great practical significance, play an important role in metabolism, the study of which is an important fundamental task (Aylangan \& Öztan, 2008; Vidal et al., 2018).

Given the shortage of raw meat, low-grade meat production, limited types of meat resources, the need to involve non-traditional sources and combine them, as well as the growing amount of PSE, DFD and RSE meat, the importance of enzyme technologies associated with the transformation and destruction of complex protein systems is increasing significantly. The use of enzymes can also solve similar problems in the dairy and fishing industries (Ghaffari-Moghaddam et al., 2014).

The world market has a fairly wide range of enzyme preparations of animal, plant and microbial origin. However, plant and especially microbial preparations, as a rule, require deeper purification. Moreover, technological regimes of food raw materials at the final production stages do not always ensure their complete inactivation, which causes problems associated with food safety (Kapreliants, 2009; Kitabatake \& Doi, 1992).

In this regard, products of animal origin are more often recommended for use in food and other technologies that do not involve the removal of enzymes as the most physiological, since they have similar properties and conditions of biocatalytic processes as enzymes of the digestive tract and cathepsins of animal muscle tissue (Kuzelov et al., 2002; Araujo et al., 2018).

Currently, a new enzyme preparation of animal origin, Protepsin, has appeared on the market of biologically active preparations.

Protepsin belongs to the class of acid proteinases (EC number 3.4.23), containing carboxyl groups in the active center. The preparation cleaves peptide bonds formed by aromatic amino acids (tyrosine, phenylalanine), and does not hydrolize esters and amides. Along with the proteolytic complex, Protepsin contains collagenase, lipase, and other digestive enzymes (Antipova et al., 2008).

The preparation is obtained according to the original technology through maceration of animal endocrine raw materials, followed by purification, concentration, isolation and freeze dehydration of the enzyme complex. Protepsin is characterized by proteolytic activity, the level of which begins from 50 units/g at pH 5.5 (Dey \& Dora, 2011). Protepsin is an enzyme preparation of animal origin, containing a complex of acidic proteinases, intended for use in the meat industry for processing raw meat. 
The enzyme composition of the preparation is developed so as to have a balanced effect on various proteins of meat and meat systems used in the technology of meat processing. Protepsin's action in the meat system is similar to intracellular enzymes (cathepsins). It produces a synergistic effect and has additional qualities that allow to apply it in a wider range of technological parameters, and also to infl uence those protein systems on which intracellular enzymes have an insignifi cant effect or do not have any effect at all (Ghaffari-Moghaddam et al., 2014).

Papain, ficine, and bromelain are major enzyme preparations of plant origin. Papain, produced from the latex of papaya fruit, has a broad substrate specificity; hydrolyzes casein, gelatin, collagen, elastin, globulin, fibrin, and other plant and animal proteins (Bhaskar et al., 2008). Papain exhibits the greatest activity in relation to actomyosin, at $60{ }^{\circ} \mathrm{C}$ hydrolyzes well not only muscle proteins but also collagen and elastin (Singh et al., 2018; Dieterich et al., 2014).

\section{Materials and methods}

\subsection{The study subjects in this paper are}

- Connective tissue from cattle by-products rich in collagen (lips and ears);

- Enzyme preparation Protepsin (standard proteolytic activity is 100 units/g) produced by ZAO Zavod Endokrinnykh Fermentov, Rzhavki settlement, Solnechnogorsky district, Moscow region, in accordance with TU 9219-005-42789257-2005, Hygiene Certificate No. 50.16.01.000.M.000638.10.07 dated October 19, 2007. General characteristics of Protepsin: light grey powder; working activity of the preparation is manifested at the temperature of $20-45^{\circ} \mathrm{C}$; the recommended rate of the preparation is intended for the condition of the system with $\mathrm{pH}$ 4.5-6.0;

- Enzyme preparation "Liquid Papain" produced by Arinor Limited, Belfour House 46-54, Great Titchfield Street, London;

- Enzyme preparation Protosublitin G10x (produced by ZAO Enzim);

- Protein hydrolyzate.

\subsection{The total proteolytic activity}

The total proteolytic activity was determined according to the requirements of GOST 20264.2-88 using the modified Anson method with Hammerstein-grade casein at $\mathrm{pH} 7.2$ as a substrate (Russian Gost, 1989). One unit of proteolytic activity was considered equal to the amount of enzyme which per 1 minute at $30^{\circ} \mathrm{C}$ turned Hammerstein-grade casein in an amount corresponding to $1 \mu \mathrm{mol}$ of tyrosine into the state in which it is not precipitated by trichloroacetic acid.

\subsection{Collagenase activity}

Collagenase activity was determined by the content of oxyproline in the mixture formed as a result of the effect of the enzyme on native collagen. For this purpose, an oxidation reagent was prepared: $28.2 \mathrm{~g}$ of chloramine $\mathrm{T}$ was dissolved in $40 \mathrm{~cm}^{3}$ of water to get a $0.05 \mathrm{M}$ concentration, $60 \mathrm{~cm}^{3}$ of acetate citrate buffer with $\mathrm{pH} 6.0$ was added. To $2 \mathrm{~cm}^{3}$ of the sample containing oxyproline $1 \mathrm{~mL}$ of the oxidation reagent was added, shaken and left for 20 minutes at room temperature. Then $1 \mathrm{~cm}^{3}$ of $4 \mathrm{M}$ perchloric acid was added to the mixture and shaken. 5 minutes later $3 \mathrm{~cm}^{3}$ of a $10 \%$ solution of $\mathrm{p}$-dimethylaminobenzaldehyde in methyl cellosolve was added. The sample was heated for 15 minutes in a water bath at $150{ }^{\circ} \mathrm{C}$ and after cooling it was scanned using a green filter of the photoelectric colorimeter FEK-56M (555 nm).

The collagen hydrolysis was carried out under the following conditions: $20 \mathrm{mg}$ of native collagen was treated with the enzyme preparation in the presence of a buffer system with $\mathrm{pH} 7.0$ so that the total volume was $25 \mathrm{~cm}^{3}$. The mixture was incubated for 1 hour at $37^{\circ} \mathrm{C}$. The mixture was controlled using samples incubated under the same conditions but without the enzyme, preliminarily stopping the reaction by adding $0.5 \mathrm{~cm}^{3}$ of ethanol and centrifuging the mixture for 15 minutes at $6,000 \mathrm{rpm}$ (Skurikhin \& Tutelyan, 1998).

\subsection{Thermogravimetric analysis}

Thermogravimetric analysis was performed on a derivatograph according to the recommendations. The change in the substance heat content with the change of temperature was recorded with Thermoscan-2, measuring the temperature difference in the sample and in the reference, which does not undergo any changes in the temperature, using two thermocouples connected to the recording device in a differential circuit.

The control of the device, temperature conditions, data collection and its processing was carried out using "Thermoscan" software (part of the supply package; suitable for the Windows 10 operating system and above). Automatic raising and lowering of the heating element. Indication of thermocouple break (Leal et al., 2015).

\subsection{Experimental design and statistical analysis}

All analyses were carried out in triplicate unless otherwise stated and the average values were calculated. The results were expressed as mean value \pm standard deviation. Significant differences between mean values at significance level $\mathrm{p}<0.05$ were established using the One-way analysis of variance and Student's test. Microsoft Excel version 2010 was used as the statistical analysis software.

\section{Results and discussion}

Protepsin, a preparation of animal origin, papain, of plant origin, and Protosubtilin G10x, of microbial origin, were the enzyme preparations under study (Table 1).

Proteolytic activity determines the degree of impact of any proteolytic enzymes on protein molecules, therefore it was necessary to determine its level for the selected enzyme preparations. In this paper, we studied total and specific proteolytic activity. 
Anson's method was used to determine total proteolytic activity, where catalytic properties are evaluated by the degree of reduction of protein substrates to low molecular weight products - peptides and amino acids, in particular, by tyrosine accumulation. According to this method, the amount of enzyme that catalyzes the conversion of $1 \mu \mathrm{mol}$ of substrate per minute at $30^{\circ} \mathrm{C}$ is taken as a unit of enzyme activity (Figure 1).

Total proteolytic activity, however, is not an absolute in the selection of an enzyme preparation for the treatment of raw materials with a high content of connective tissue. It is known that different enzymes affect protein substrates in a different way. A prepararion with a high proteolytic activity may be inert towards collagen, may not be able to cleave this main stroma protein. Therefore, a study was conducted to determine the specific effect of preparations on collagen (Neklyudov \& Ivankin, 2007; Khoshnoodi et al., 2006). Bovine tendons collagen was used for the comparative study of the dependence of the collagenolytic activity of the selected enzyme preparations on the temperature

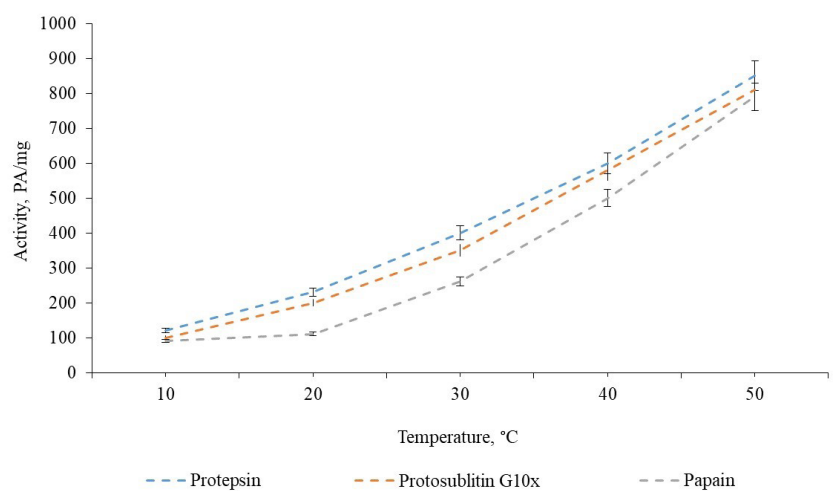

Figure 1. Comparative Proteolytic Activity of Enzyme Preparations.

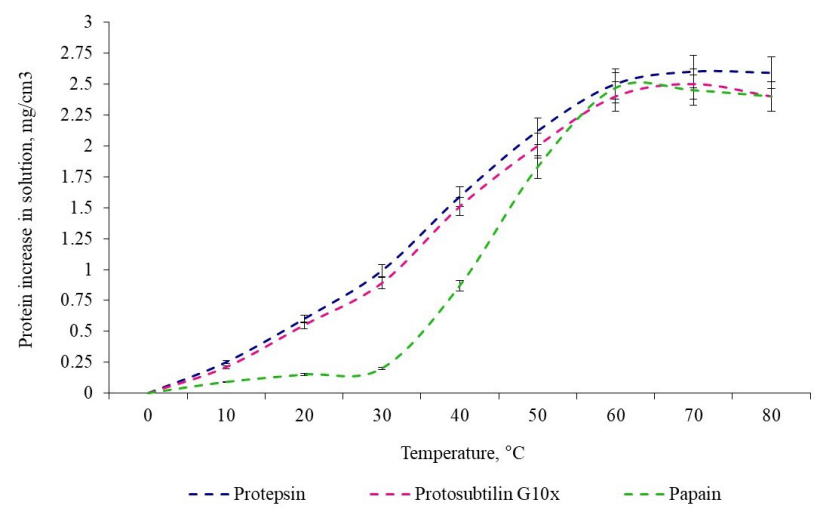

Figure 2. Dependence of Collagen Proteolysis on the Temperature of the Medium. of the medium. The increase of protein in the solution was considered an indicator of activity. The collagenolytic activity was determined at $\mathrm{pH} 6.8$ (natural for raw materials).

The results of the comparative study of the degree of collagen proteolysis under the action of Protepsin and Protosubtilin G10x, depending on temperature, are illustrated in Figure 2.

As can be seen in the figure, the effect of papain on collagen at the temperature of $0-30^{\circ} \mathrm{C}$ is low and remains almost unchanged. A further increase in temperature leads to a sharp increase in the papain activity. At $30-40{ }^{\circ} \mathrm{C}$ its activity increases by 5.27 times. Such behavior of the enzyme confirms the lack of specificity for collagen at temperatures below denaturation.

On the contrary, Protepsin and Protosubtilin G10x cause a significant (compared with papain) increase in protein in the solution already at low temperatures. A further increase in temperature leads to an increase in the activity of the enzyme preparations.

Thus, the collagenolytic activity of papain is manifested to a greater extent at temperatures close to protein denaturation, while Protepsin and Protosubtilin G10x are able to significantly hydrolyze native collagen as well.

Studies of the enzyme preparations effect have clearly shown that the temperature range of $35-45^{\circ} \mathrm{C}$ is optimal from the point of enzymes greatest activity and stability.

In general, the results of the study of proteolytic activity call for further research of Protepsin, which has a greater collagenolytic activity, making it promising for the hydrolysis of collagen-containing raw materials (Mandl, 2000).

The change in the substance heat content with the change of temperature was recorded with Thermoscan-2, measuring the temperature difference in the sample and in the reference, which does not undergo any changes in the temperature, using two thermocouples connected to the recording device in a differential circuit (Saldarriaga et al., 2015).

Figure 3 shows the DTA curves of the native raw material and protein hydrolyzate in relation to the reference.

To obtain the curves of differential thermal analysis (DTA), a series of experiments was carried out involving an organic compound, phenanthrene, as a reference sample. Figure 4 shows thermograms of native raw materials and protein hydrolyzate.

Laboratory tests indicate that the DTA curve for untreated collagen has two endothermic peaks. Peak 1 indicates the process of collagen denaturation in the temperature range of $60{ }^{\circ} \mathrm{C}$. At $65{ }^{\circ} \mathrm{C}$, the process of collagen denaturation continues (peak 2), but becomes less intensive. Peak 1 corresponds to the release of free moisture from the collagen fraction of the protein

Table 1. Biochemical characteristics of enzyme preparations.

\begin{tabular}{llccc}
\hline \multirow{2}{*}{ Enzyme Preparations } & \multicolumn{1}{c}{ Source } & \multicolumn{2}{c}{ Indicators } \\
\cline { 2 - 5 } & \multicolumn{1}{c}{ proteolytic activity Unit/g } & acidic optimum, $\mathrm{pH}$ & thremal optimum, ${ }^{\circ} \mathrm{C}$ \\
\hline Protepsin & Birds gastric mucosa & 100.0 & $4.5-6.0$ & $35.0-45.0$ \\
Papain & Papaya & 250.0 & $5.0-7.0$ & 60.0 \\
Protosublitin G10x & Bacillus subtilis & 400.0 & $7.0-7.2$ & 40.0 \\
\hline
\end{tabular}


(primarily osmotic and mechanical bound moisture, as well as a small part of the weakly bound adsorption moisture of the outer molecular layers of collagen) (Margander, 1995). Peak 2 corresponds to dehydration of protein substances with the complete decomposition of their native structure as a result of hydrolytic action of the enzyme preparation that is accompanied by the release of gaseous products and the removal of the chemical bound form of moisture.

A part of the osmotic and immobilized bound moisture is retained in closed cells of fibrillar structures, which is subsequently released with increasing temperature, and its release occurs at the temperature of $30-50{ }^{\circ} \mathrm{C}$.

With the temperature rise to $50{ }^{\circ} \mathrm{C}$, there occurs a sharp change in the mass of the test sample, indicating an intense release of free moisture and the development of denaturation processes. The similar course of the curves on the thermograms corresponding to the test and control samples confirms changes in the thermophysical characteristics of the collagen fractions.

Such two-stage denaturation process was noted by researchers earlier. The process of denaturation of collagen in the protein hydrolyzate, as is seen in the curve, begins at $45-55^{\circ} \mathrm{C}$ and ends at $80^{\circ} \mathrm{C}$. Thus, collagen denaturation after treating the collagen-containing raw material with Protepsin shifts to lower temperatures, indicating the dispersing effect of the enzyme preparation on the native collagen protein.

The change in the mass loss of the native raw material and protein hydrolyzate during heat treatment is shown in Figure 5.

The DTA study of samples once again confirmed the depth of changes that occurred as a result of the enzymatic processing of raw material.

To prepare a protein hydrolyzate, the collagen-containing raw materials was washed with running water at $18-20{ }^{\circ} \mathrm{C}$ for 20 minutes and fleshed. Afterwards it was ground on the top with a hole diameter of 2-3 mm. The ground material was poured with Protepsin, pre-dissolved in water. The amount of water necessary was determined in an empirical way, so that the treated raw material was completely covered with the liquid. The mixture was heated to $40-45^{\circ} \mathrm{C}$. Protepsin was introduced in the amount of $0.1 \%$ by weight of the raw material; the hydrolyzation was carried out during 1.5-2 hours. After being hydrolized, the mixture was heated to $80-90^{\circ} \mathrm{C}$ for $15-20$ minutes in order to inactivate the enzyme preparation. Excess moisture was removed using a sieve. The mixture was ground and homogenized (Figure 6).

Organoleptic evaluation of protein hydrolyzate is given in Table 2.

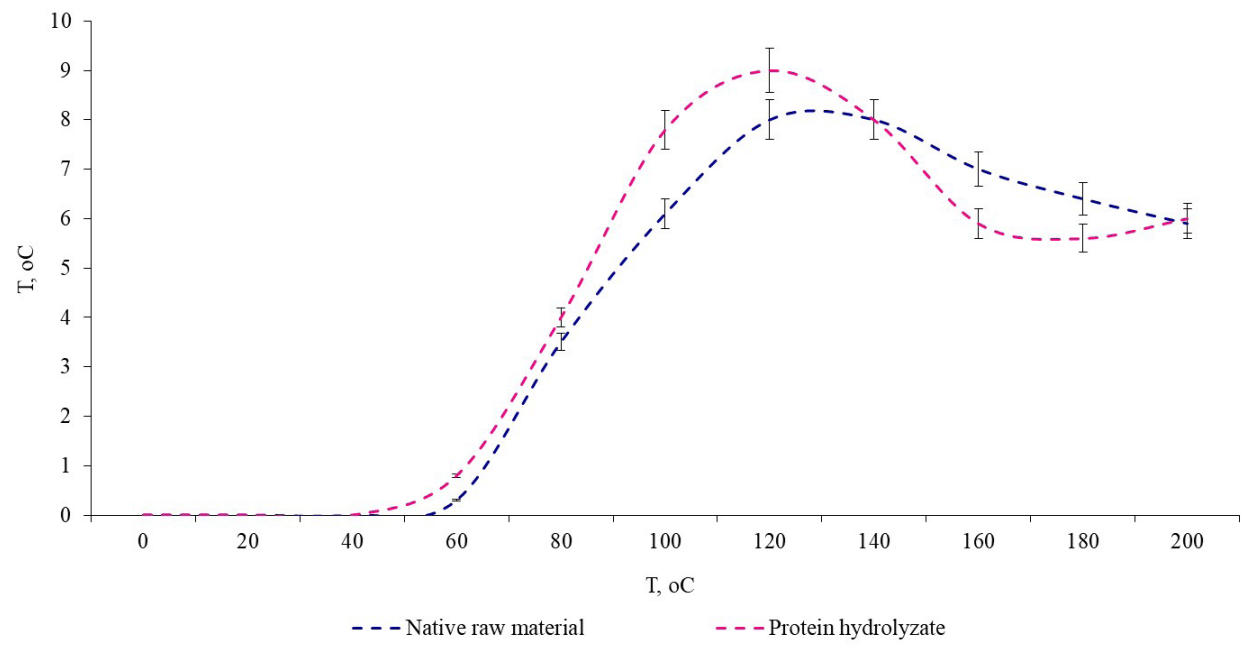

Figure 3. DTA Curves of Native Raw Material and Protein Hydrolyzate.

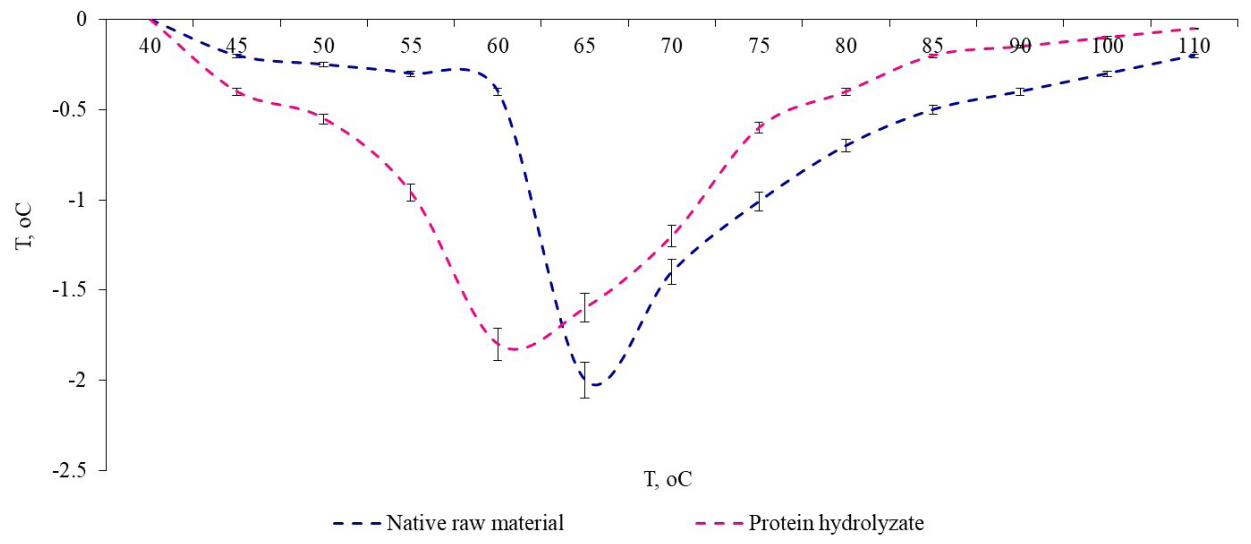

Figure 4. Thermograms of Native Raw Materials and Protein Hydrolyzate. 


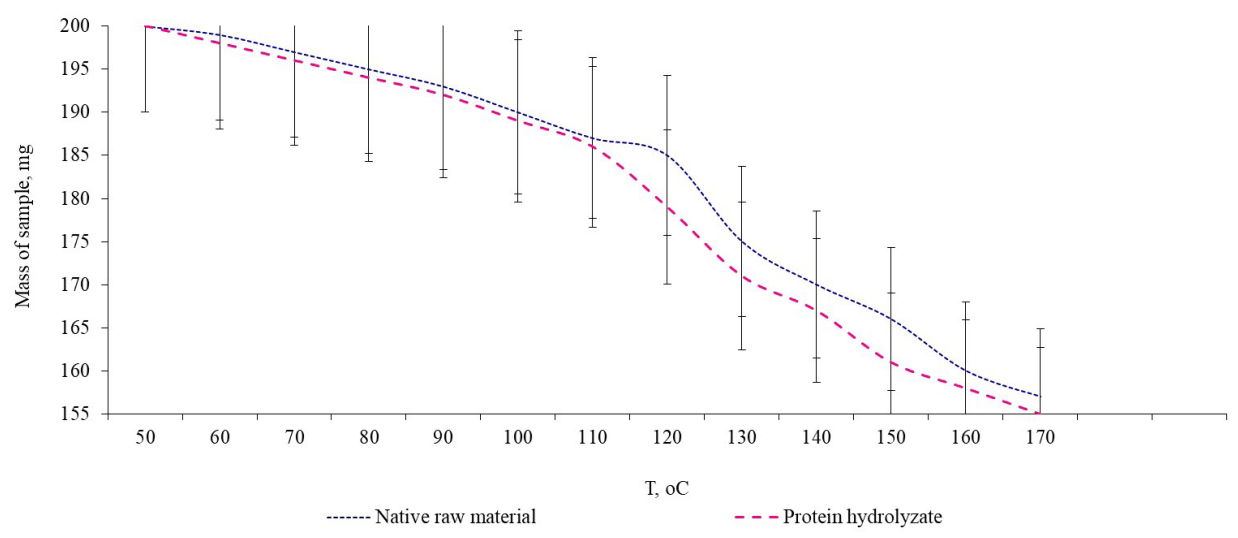

Figure 5. The Change in the Mass Loss of Native Raw Materials and Protein Hydrolyzate During Heat Treatment.

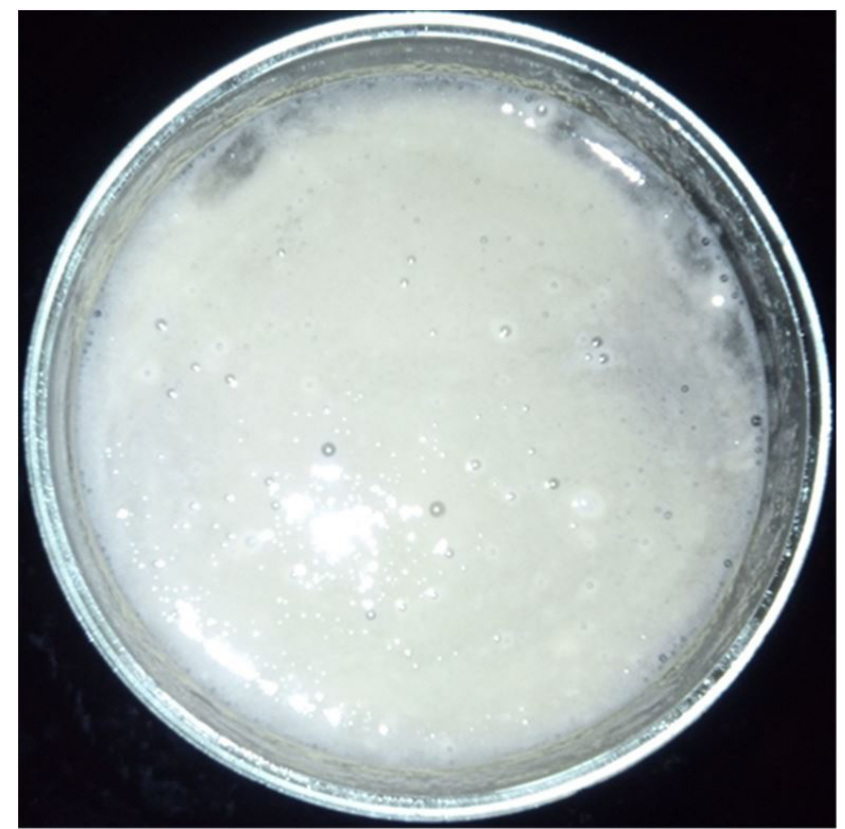

Figure 6. Appearance of Protein Hydrolyzate.

Table 2. Organoleptic evaluation of protein hydrolyzate.

\begin{tabular}{ll}
\hline \multicolumn{1}{c}{ Indicator } & \multicolumn{1}{c}{ Characteristics } \\
\hline Color & Creamy, homogeneous throughout the mass \\
Smell & Corresponds to the product name, without foreign smell \\
Transparency & Nontransparent \\
Taste & Corresponds to the product name \\
Consistency & Sticky \\
Appearance & Homogeneous, without layering \\
\hline
\end{tabular}

Samples of protein hydrolyzate were tested for storage stability under laboratory conditions, at $6-12{ }^{\circ} \mathrm{C}$. It was found that the average storage time of protein hydrolyzate is $2-3$ days.

\section{Conclusion}

The results of the laboratory studies of the proteolytic activity of enzyme preparations show that Protepsin, the preparation of animal origin with a proteolytic activity of 100 units/g, has the greatest collagenase activity in the biomodification of native collagen-containing raw materials. The perfect hydrolysis temperature of collagen-containing raw materials is $30-45^{\circ} \mathrm{C}$.

To prepare a protein hydrolyzate, the collagen-containing raw materials was washed with running water at $18-20{ }^{\circ} \mathrm{C}$ for 20 minutes and fleshed. Afterwards it was ground on the top with a hole diameter of 2-3 $\mathrm{mm}$. The ground material was poured with Protepsin, pre-dissolved in water. The amount of water necessary was determined in an empirical way, so that the treated raw material was completely covered with the liquid. The mixture was heated to $40-45^{\circ} \mathrm{C}$. Protepsin was introduced in the amount of $0.1 \%$ by weight of the raw material; the hydrolyzation was carried out during 1.5-2 hours. After being hydrolized, the mixture was heated to $80-90{ }^{\circ} \mathrm{C}$ for $15-20$ minutes in order to inactivate the enzyme preparation.

We also carried out the differential thermal analysis of native raw materials and protein hydrolyzate. The results of the DTA study of samples once again confirmed the depth of changes that occurred as a result of the enzymatic processing of raw materials. The obtained organoleptic indicators of protein hydrolyzate indicate the possibility of its use in the food and pharmaceutical industry, for the production of sports nutrition and biologically active preparations.

\section{Acknowledgements}

The work was supported by Act 211 of the Government of the Russian Federation, contract n 02.A03.21.0011.

\section{References}

Antipova, L. V., Podvigina, I. N., \& Kosenko, I. S. (2008). Use of enzyme preparations in the meat production process. Fundamental Research, 6, 134-135.

Araujo, I. B. S., Bezerra, T. K. A., Nascimento, E. S., Gadelha, C. A. A., Santi-Gadelha, T., \& Madruga, M. S. (2018). Optimal conditions for obtaining collagen from chicken feet and its characterization. Food Science and Technology, 38(Suppl. 1), 167-173. http://dx.doi. org/10.1590/fst.27517.

Aylangan, A., \& Öztan, A. (2008). Protein hydrolyzate production using by-products of animal food industry. In Turkey 10. Food Congress. 
Kahramanmaras: Kahramanmaras Sutcu Imam University Esenyurt Üniversitesi Avsar Kampusu.

Bhaskar, N., Benila, T., Radha, C., \& Lalitha, R. G. (2008). Optimization of enzymatic hydrolysis of visceral waste proteins of Catla (Catlacatla) for preparing protein hydrolysate using a commercial protease. Bioresource Technology, 99(2), 335-343. http://dx.doi.org/10.1016/j. biortech.2006.12.015. PMid:17303414.

Bobuş, G. (2010). Determination of functional and bioactive properties of lentil protein concentrate and hydrolysate (Master thesis). Mersin University, Mersin.

Dey, S. S., \& Dora, K. C. (2011). Optimization of the production of shrimp waste protein hydrolysate using microbial proteases adopting response surface methodology. Journal of Food Science and Technology, 48(6), 699-705. http://dx.doi.org/10.1007/s13197010-0197-8. PMid:24426043.

Dieterich, F., Boscolo, W. R., Pacheco, M. T. B., Silva, V. S. N., Gonçalves, G. S., \& Vidotti, R. M. (2014). Development and characterization of protein hydrolysates originated from animal agro industrial byproducts. Journal of Dairy. Veterinary and Animal Research, 1(2), 1-7. http://dx.doi.org/10.15406/jdvar.2014.01.00012.

Ghaffari-Moghaddam, M., Eslahi, H., Omay, D., \& ZakipourRahimabadi, E. (2014). Industrial applications of enzymes. Review Journal of Chemistry, 4(4), 341-361. http://dx.doi.org/10.1134/ S2079978014040037.

Kapreliants, L. V. (2009). Enzymes in food technology. Odessa: Druk.

Khoshnoodi, J., Cartailler, J. P., Alvares, K., Veis, A., \& Hudson, G. B. (2006). Molecular recognition in the assembly of collagens: terminal noncollagenous domains are key recognition modules in the formation of triple helical protomers. The Journal of Biological Chemistry, 281(50), 38117-38121. http://dx.doi.org/10.1074/jbc. R600025200. PMid:17082192.

Kitabatake, N., \& Doi, E. (1992). Denaturation and texturization of food protein: food extrusion science and technology (pp. 361-371). New York: Marcel Dekker.

Kuzelov, A., Vasilev, K., \& Velkova, K. (2002). Influence of microbial enzyme preparation upon structural and mechanical properties of meat raw materials from big ruminants. Food Tasting Industry, 4, 13-14.

Leal, G., Ramos, L., Barrett, D., Curvelo, A., \& Rodella, C. (2015). A thermogravimetric analysis (TGA) method to determine the catalytic conversion of cellulose from carbon-supported hydrogenolysis process. Thermochimica Acta, 616, 9-13. http://dx.doi.org/10.1016/j. tca.2015.07.017.

Mandl, I. (2000). Collagenases and elastases: advances in enzymology (pp. 123-125). London: Interscience Publishers.

Margander, K. (1995). Collagen proteins as aids to improve the technological and sensory characteristics of meat products and ready meals. Fleicshwirtschaft, 75(11), 1286-1287.

Neklyudov, A. D., \& Ivankin, A. N. (2007). Collagen: production, properties and application. Moscow: Publishing House MGUL.

Russian Gost. (1989). GOST 20264.2-88: enzyme preparations: methods for determination of proteolytic activity (pp. 14). Moscow.

Saldarriaga, J., Aguado, R., Pablos, A., Amutio, M., Olazar, M., \& Bilbao, J. (2015). Fast characterization of biomass fuels by thermogravimetric analysis (TGA). Fuel, 140, 744-751. http://dx.doi.org/10.1016/j. fuel.2014.10.024.

Singh, T. A., Sarangi, P. K., \& Singh, N. J. (2018). Tenderisation of meat by bromelain enzyme extracted from pineapple wastes. International Journal of Current Microbiology and Applied Sciences, 7(9), 32563264. http://dx.doi.org/10.20546/ijcmas.2018.709.404.

Skurikhin, I. M., \& Tutelyan, V. A. (1998). A guide to the methods of analyzing food quality and safety (pp. 23-37). Moscow: Brandes.

Spohner, S. C., Müller, H., Quitmann, H., \& Czermak, P. (2015). Expression of enzymes for the usage in food and feed industry with Pichia pastoris. Journal of Biotechnology, 202, 118-134. http://dx.doi. org/10.1016/j.jbiotec.2015.01.027. PMid:25687104.

Vidal, A. R., Ferreira, T. E., Mello, R. O., Schmidt, M. M., Kubota, E. H., Demiate, I. M., Zielinski, A. A. F., \& Dornelles, R. C. P. (2018). Effects of enzymatic hydrolysis (Flavourzyme ${ }^{\circ}$ ) assisted by ultrasound in the structural and functional properties of hydrolyzates from different bovine collagens. Food Science and Technology, 38(Suppl. 1), 103-108. http://dx.doi.org/10.1590/fst.16717. 